\title{
РИБНІ ГОСПОДАРСТВА ЯК ОСЕРЕДКИ БІОЛОГІЧНОГО РОЗМАЇТТЯ
}

\author{
Причепа М. В., Коваленко Ю. О.
}

\section{ВСТУП}

Антропогенна діяльність охоплює все більше простору в природних екосистемах, iï посилення часто супроводжується рекреаційним навантаженням на водно-болотні угіддя. Це впливає на присутність та успішність гніздування низки видів птахів на зазначених територіях. Для значної кількості видів водно-болотних птахів зазначені чинники становлять суттєву загрозу, зокрема для життя та відтворення.

Натомість своєрідною альтернативою втраченим місцям існування стали штучно створені екосистеми, а саме рибні господарства (РГ) каскадного типу, які завдяки наявності різних біотопів змогли повноцінно замінити багатьом видам птахів їх природне середовище існування.

Тепловодне РГ зазвичай має значну площу з малопроточними та неглибокі ставами, що мають сприятливі умови для розвитку організмів бентосу. На повноциклічних РГ кожен став має свої характеристики i призначення. Так, головний став найбільший, він накопичує воду перед подачею до інших ставів. Як правило такі водойми можуть використовувати ниркові качки, баклани, гагари, пірникози, а також там можуть полювати орлан-білохвіст та скопа.

У малькових ставах площею $0,5-1,5$ га та глибиною $0,5-0,8$ м підрощують личинок. Ці стави здебільшого розташовані на сонячній стороні, через що добре прогріті та збагачені мікроорганізмами ${ }^{1}$ На них можуть перебувати деякі кулики та качки.

Вирощувальні стави зазвичай мають площу 10-15 га та глибину 1,0-1,2м. Призначені для вирощування мальків до настання осені.

Нагульні стави мають площу 50-400 га, у них вирощують товарних риб. Вирощувальні та нагульні стави не мають значних глибини, а з настанням осені їх повністю спускають для обловів і залишають спущеними до весни. Як правило, такі ставки мають відносно високий рівень заростання прибережно-водною рослинністю (осока, очерет,

${ }^{1}$ Андрющенко А.І., Алимов С.I. Ставове рибництво. Київ : Видавничий центр HAУ, 2008. C. 636. 
рогіз). Це сприяє утворенню на них колоніальних угруповань різних представників сивкоподібних (мартини, крячки), пірникоза, різних видів качок, чаплі. Завдяки багатій фауні макрозообентосу тут сприятливі кормові умови для куликів. Також на них впродовж сезону відгодовуються представники різних систематичних груп птахів, приурочених до водного середовища. Після облову підрощених риб та риб інших вікових груп їх пересаджують у зимувальні стави 3 глибиною не менше 1,2 метри та площею 0,$5 ; 1$ чи 1,5 га., а ложе вирощувальних та нагульних ставів можуть залишити промерзати до весни, тому під час весняної міграції на них можуть зупинятись значна кількість куликів.

Під час вирощування риб ложе ставів часто удобрюють для збільшення кількості кормових об'єктів риб та додатково вносять рибні корми. Крім того, один раз на 5-7 років на нагульних та вирощувальних ставах проводять літування задля дотримання санітарно-профілактичних заходів. Через це впродовж року один із зазначених ставів залишають без води. На ложі ставу проводять меліоративні роботи та засівають такими культурами, як пшениця, люпин чи віко-вівсяна суміш, тому навесні створюються оптимальні умови для гніздування та перебування куликів.

Через екологічні умови, що склались на РГ ставах, існує необхідність проведення моніторингових досліджень видового й кількісного складу мігруючих та гніздових видів, зокрема, у межах міст. Порівняння отриманих результатів моніторингу зі штучно створеними ставами, на яких не здійснюється аквакультура, дає змогу оцінити перевагу рибогосподарських ставів як осередок біологічного різноманіття.

\section{1. Видовий склад птахів та їх статус на окремих рибних господарствах Кисва та Білої Церкви}

Дослідне господарство «Нивка» Інституту рибного господарства НААН України територіально розташоване в м. Києві, у межах Правобережного Полісся і Дніпровського екологічного коридору ${ }^{2}$, має площу 214,4 га земельних ресурсів, 3 них 181,4 га становлять водойми ${ }^{3}$ Ставки мають різну глибину та площу. Найбільший 3 них «Святошинський став» має довжину 1,5 км. Став характеризується

2 Казанник В.В., Турчик А.В., Яненко В.О. Водно-болотяна орнітофауна Святошинських ставків м. Києва та ï сезонні зміни. Вісник Дніпропетровського агро-економічного університету. 2014. № 1 (33). С. 170-174.

Офіційний сайт ДП «Дослідне господарство «Нивка»». URL: http://www.if.org.ua/index.php/uk/departments/nyvka (дата звернення: 01.12.2020). 
високим рівнем заростання повітряно-водяною рослинністю, очеретом звичайним (Paragmites australis) та рогозом широколистним (Typha latifolia) ${ }^{4}$. Останні стави мають невелику площу (1,5-2 га). Їх повністю спускають у осінній період та наповнюють восени. Ставки тісно межують із листяним та мішаним лісом, який $€$ частиною Національного природного парку «Голосіївський», а також із відкритою долиною, яка простягається вздовж р. Ірпінь.

Господарство повноциклічне, на ньому вирощують племінні породи коропа (Cyprinus carpio) від ікри до товарної риби та утримують плідників. Також наявні такі види, як білий амур (Ctenopharyngodon idella), білий товстолоб (Hypophthalmichthys molitrix), плітка звичайна (Rutilus rutilus), краснопірка звичайна (Scardinius erythrophthalmus), карась китайський (Carrasius auratus), гірчак європейський (Rhodeus amarus), амурський чебачок (Pseudorasbora parva), окунь річковий (Perca fluviatilis), йорж (Gymnocephalus cernиa), бичок-бабка (Neogobious fluviatilis), бичокгонець (Babka gymnotrachelus), колючка триголкова (Gasterosteus aculeatus), сом європейський (Silurus glanis), пічкур звичайний (Gobio gobio), щипавка звичайна (Gobitis taenia). Більшість видів риб, які вирощуються на господарствах, зустрічаються у природних водоймах і можуть бути характерними для р. Ірпінь та р. Нивка.

Розгалужена система каналів, заболочені частини лісу та відкриті частини узлісь відіграють важливу роль в існуванні сухопутних та болотних хребетних тварин, а саме озерної жаби (Pelophylax ridibundus), трав'яної жаби (Rana temporaria), райки (Hyla arborea), кумки звичайної (Bombina bombina), ропухи сірої (Bufo bufo), вужа водяного (Natrix natrix), болотяної черепахи європейської (Emus orbicularis), бобра річкового (Castor fiber), ондатри (Ondatra zibethicus), щура водяного (Arvicola amphibius).

Важливим $є$ те, що ставки дослідного господарства «Нивка» та прилеглих до нього територій занесено в території Смарагдової мережі.

Схема дослідного господарства наведена на рис. 1.

На рекреаційній частині господарства «Нивка» наявні заболочені ділянки, які поросли очеретом та іншими вищими водними рослинами. Через це під час весняної міграції їх використовують чирянка мала, чирянка велика, свищ (Anas penelope) (5-7 особин), чернь чубата (Aythya fuligula) (2-5 особин), широконіска (Anas clypeata) (3-6 особин), коловодник лісовий (Tringa ochropus) (3-6 особин), коловодник болотяний (Tringa glareola) (10-15 особин). Так, протягом 2019-2020 рр. на ставках Нивка та прилеглих територіях було

\footnotetext{
${ }^{4}$ Вишневський В.І. Малі річки Києва. Київ : Інтерпрес. ЛТД, 2013. 84 с.
} 
зареєстровано гніздування 79 видів. Слід зауважити гніздування таких видів, як пірникоза велика (6-8 пар), пірникоза мала (1-2 пари), лебідьшипун (1 пара), лиска, крижень, чирянка мала (1 пара), пастушок (1 пара), бугайчик, курочка водяна, ремез, очеретянка (велика, чагарникова, лугова), кобилочка солов’їна. Наявні колонії крячка чорного та мартина звичайного. На зарослих рогозою і очеретом берегах ставу наявні гніздові угруповання синиці вусатої. Також у 2019 р. під час токового співу реєструвався погонич звичайний. На одному із ставів було зареєстровано чернь білооку (Aythya nyroca) (18 травня 2019 р.) $)^{5}$ що плавала разом із попелюхами (Aythya ferina).

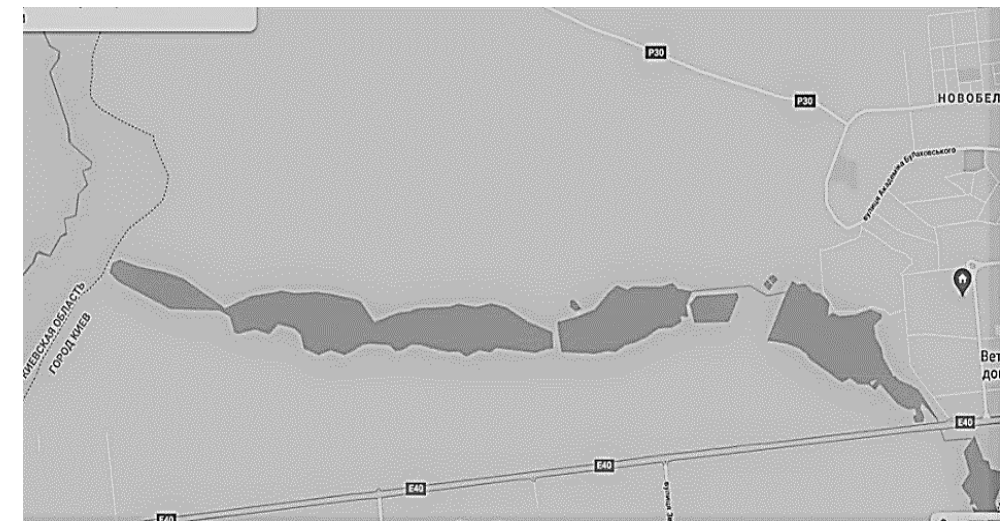

Рис. 1. Дослідницьке РГ «Нивка»

Під час осінньої міграції зазначені заболочення, що розташовані вздовж р. Нивка, використовують яструб малий та яструб великий, канюк звичайний, чирянка мала. У зимовий період через відсутність льодоставу на окремих ділянках водойми зимували такі види, як крижень (Anas phatyrhynchos), чепура велика (Egretta alba), чапля сіра (Ardea cinerea), лиска, мартин жовтоногий (Larus cachinnans), мартин звичайний. Навіть вдало зуміла перезимувати одна особина пірникози великої. 23 жовтня 2019 р. було зареєстровано одну особину підсоколика малого (Falco columbarius).

Середні стави характеризуються піщаним дном та високим рекреаційним навантаженням. Також на одному зі ставків наявна зона

5 Причепа М.В. Видовий склад і населення хижих та гідрофільних птахів лук та водно-болотних угідь окремих частин Києва та його околиць. Беркут. 2019. Т. 28. Вип 1-2. С. 6-14. 
коштовної риболовлі. Біля цих ставів протягом гніздового сезону реєструються яструб великий, яструб малий та канюк звичайний, що може свідчити на користь гніздування цих видів у прилеглих ділянках лісу. У весняний період, коли ложе ставу без води, його використовують кулики, зокрема побережники, грицик великий (Limosa limosa), коловодник звичайний (Tringa totanus), коловодник великий, та мартини (звичайний, сивий, жовтоногий) для відгодівлі під час міграції (табл 1). Також у незначній кількості у весняний період протягом квітня-травня 2019 р. траплялися коловодник чорний, коловодник ставковий. Слід зауважити про реєстрацію протягом гніздового сезону на цих водоймах пісочника малого та набережника (Actitis hypoleucos). Протягом 2019 р. тут було знайдено гніздову пару набережника.

У кінці травня або початку червня стави знову заливають водою. В цей час приступають до гніздування пірникоза велика (Podiceps cristatus), лиска, курочка водяна. Через пізне наповнення ставка водою птахи 3 деякою затримкою приступають до розмноження порівняно зі своїми родичами, які вибрали перші стави, що були постійно залиті водою. Протягом травня (5-20 травня 2019 р.) на Святошинському ставку та прилеглій до нього території, зокрема заболочені низини вздовж трансформованого русла р. Нивка, реєструвались крячки чорний (20-40 особин) і світлокрилий (25-30 особин).

У літній період на середніх ставках тривалий час трималась пара мандаринок (Aix galericulata). Через певний час реєструвався лише самець, самиця у той час могла перебувати на гнізді. Слід зазначити про реєстрацію на цих водоймах у осінній період таких видів, як крех великий (Mergus merganser), гагара чорношия (Gavia arctica), чернь морська (Aythya marila).

На передостанніх ставах із кінця червня по кінець серпня трималась чернь чубата. Також реєструвались чирянка мала, пірникоза мала, крячок річковий, крячок білощокий. Протягом гніздового сезну на цьому ставі реєструвались підорлик малий (Aquila pomarina), змієїд, осоїд (Pernia apivorus), шуліка чорний (Milvus migrans), підсоколик великий (Falco subbuteo, чорний лелека (Ciconia nigra), канюк звичайний. Реєстрація останнього може свідчити про гніздування у прилеглих до ставків ділянках лісу. Так, зокрема, у 2019 р. у мішаному лісі було знайдено гніздо канюка звичайного, розміщене на сосні. У гнізді було двоє пташенят. Також протягом 2019 р. на цих ставках протягом липня та серпня реєструвались мігруючі групи рудої чаплі (2-12 особин). Також неподалік цих водойм було зареєстровано підорлика великого (Aquila clanga) (23 жовтня 2019 р.), що був атакований групою звичайних канюків. 
У період осінньої міграції на передостанніх та останніх ставах зупиняються гуменник (Anser fabalis), крех великий (Mergus merganser), гагара чорношия (Gavia arctica), чернь морська (Aythya marila), попелюх (Aythya ferina), лебідь-шипун (Cygnos olor), скопа (Pandion haliaetus). Під час осушення ложе ставу тут реєструються зграї таких видів, як баклан великий, чепура велика, чапля сіра, мартин звичайний та крижень. У зимовий період (26 січня 2020 р.) був відмічений орлан-білохвіст (Haliaeetus albicilla).

Останній став має глибину до метра, дно 3 невеликим прошарком мулу, оптимальним для розвитку безхребетних організмів. Цей став межує з лісом та долиною річки Ірпінь, через що ця ділянка приваблює хижаків для гніздування та полювання (рис. 2а). Так, неподалік гніздяться осоїд (Pernis apivorus), підорлик малий (Aquila pomarina), шуліка чорний, підсоколик великий (Falco subbuteo), лунь очеретяний, канюк звичайний. Слід зауважити, що неподалік ставка було зареєстровано гніздову пару канюка звичайного, зокрема протягом весни неодноразово спостерігали птаха 3 гніздовим матеріалом та кормом. Шуліка чорний неодноразово реєструвався на останніх ставках, використовуючи територію як кормові майданчики. Слід зазначити реєстрацію протягом гніздового сезону цього птаха іншими дослідниками ${ }^{6} .3$ водоплавних зареєстровано гніздування пірникози малої. Також у весняний період реєструвалась пірникоза чорношия. Саме на цьому ставку стаціонарно 311 травня до середини серпня годувався лелека чорний (Ciconia nigra) (рис. 2б). Неодноразово на цих ділянках реєстрували двох особин цього виду одночасно.

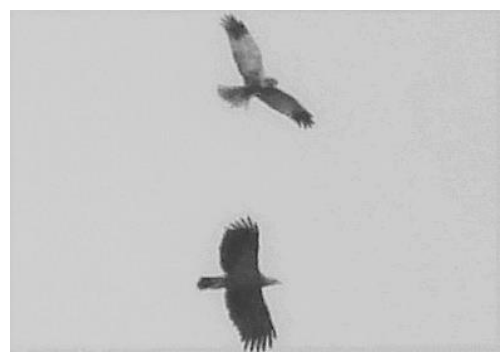

a)

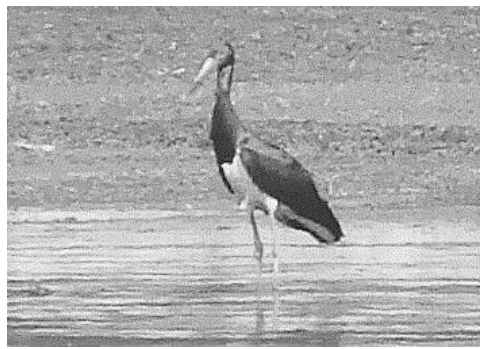

б)

Рис. 2. а) підорлик малий та лунь очеретяний; б) лелека чорний під час харчування на останньому ставу рибного господарства «Нивка»

6 Костюшин В.А., Домашевский С.В., Грищенко В.Г. Материалы по распространению черного коршуна (Milvus migrans) в Киевской области в гнездовый период. Беркут. 2015. Т. 24. Вып. 1. С. 42-46. 
Незважаючи на розташування господарства поруч із густозаселеним районом Києва, тут зосереджено значне біорізноманіття видового складу орнітофауни різних екологічних груп птахів. Крім уже розглянутих, зареєстровано додатково 93 види (серед них слід назвати сорокопуда сірого (Lanius exubitor) та голуба-синяка (Columba oenas), занесених до Червоної книги України). Проте існують загрози біологічному розмаїттю, пов'язані з потужним тиском рекреації та окремих частин водойм. Через це відчувають дискомфорт особливо чутливі представники орнітофауни.

Білоцерківські нагульні ставки та Боровецькі ставки розміщені поруч і використовуються як неповносистемні господарства, у яких у полікультурі вирощують коропових видів риб до товарних розмірів (короп, білий амур, гібриди товстолоба). Ставки мають площу 2 га та 124,56 га відповідно (Кадастрова карта). Вони розташовані у межах лісостепу. Ставки наповнюються водою з р. Протока. Також у ставках наявні такі види, як окунь річковий, ротан-головешка (Perccottus glenii), вівсянка звичайна (Leucaspius delinaetus), амурський чебачок, карась китайський, йорж звичайний. На господарстві існують такі види гідрофільних тварин, як жаба гостроморда (Rana arvalis), райка, ропуха cipa, жаба озерна, бобер річковий, кутора звичайна (Neomys fodiens), ондатра, вуж звичайний, черепаха болотяна європейська.

Загальна схема господарства представлена на рис. 3 .

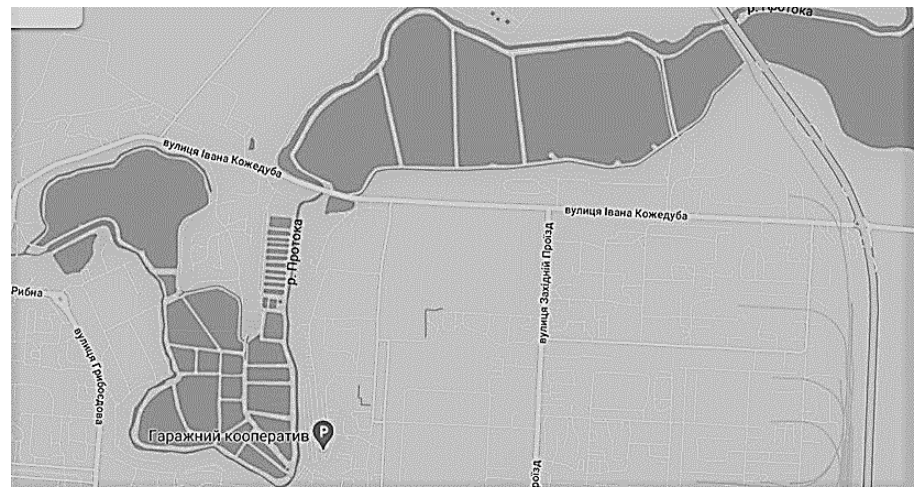

Рис. 3. Ставки риборозплідників Білої Церкви

Водойми розділені між собою дорогою та приватним сектором. Ставок 1 використовується як платна риболовля й має площу 8 га. Значна площа ставу вкрита прибережно-водною рослинністю, зокрема очеретом. Виявлено, що на цій водоймі наявні колоніальні угруповання 
мартина звичайного (30-45 пар) та крячка білощокого (37-42 пари), які влаштовують свої гнізда на заломах рогози та рдеснику (Potamogeton $s p$.$) . Слід зауважити про відносно пізнє гніздування у окремих крячків$ (липень). Також на водоймі виявлено гніздування таких видів, як пірникоза велика (5 пар), пірникоза чорношия (4-5 пар), пірникоза мала (1 пара), попелюх (2 пари), лебідь-шипун (1 пара -8 juv), крижень, лиска, водяна курочка. На водоймі протягом літа трималися зграї мартина жовтоногого. Також слід сказати про реєстрацію двох особин крячка малого (ЧКУ) (14 травня 2020 р.). У осінній період їх зграї становили до 450 особин. 3 огляду на те, що значна частина ставу вкрита очеретом, це дає можливість гніздитися деяким гідрофільним видам, приуроченим до таких екологічних умов, таким як лунь очеретяний (1 пара), чапля руда (1 пара), бугай (3-4 пари), бугайчик, вусата синиця, вівсянка очеретяна, пастушок (2-3 пари), погонич звичайний (Porzana porzana) і погонич малий (Porzana parva). Додатковим біотопом для чагарникових видів птахів $\epsilon$ заболочена низина колишнього ставу, який не функціонує. Це, зокрема, стосується очеретянки лугової (Acrocephalus schoenobaenus) та очеретянки чагарникової (Acrocephalus palustris), які у зазначеному біотопі переважали.

Водойми № 2, 3, 4, 5 використовуються для підрощування молоді риб до товарної маси. Характерною особливістю цих водойм $\epsilon$ незначний відсоток заростання вищою водяною рослинністю. Також вони характеризуються глинисто-піщаним типом грунтів. Весною на них проводять літування. Це сприяе появі на ставах куликів. Так, зокрема, було зареєстровано протягом квітня-травня такі види: брижач (Philomachus pugnax) (6-20 (особин), коловодник болотяний (4-45 особин), пісочник малий (4-8 особин), коловодник звичайний (2-4 особини), коловодник великий (2 особини), коловодник лісовий (4 особини), набережник (2-6 особин), чайка (2-8 особин), побережник чорногрудий (Calidris ferruginea) (2-4 особини). Варто зауважити, що птахи тримаються на ставках до повного залиття їх водою, окремі види влаштовують на них гнізда. Так, було зареєстровано 2 пари пісочника малого, 1 пару коловодника звичайного, 2 пари чайки. Також на ставку № 3 було виявлено колонію крячка білощокого (8 пар), крячка річкового (1 пара), 17 пар мартина звичайного. Гнізда птахи влаштовували на залитих водою острівцях з осоки та очерету. 3 огляду на те, що ставки використовуються для підрощування личинок і мальків коропових риб, у них рівень води впродовж тривалого часу $\epsilon$ незначним для кращого прогрівання водойми. Це сприяє утворенню острівців, на яких тримаються водоплавні та коловодні птахи. Ставки № 6, 1 та 7 характеризуються значним відсотком заростання водойми 
очеретом. Тут на гніздуванні наявні пара очеретяного луня, дві пари бугая, бугайчик, крижень, очеретянка чагарникова, очеретянка ставкова, очеретянка велика, синьошийка, вусата синиця. Вздовж дамб і кущів протягом сезону досліджень постійно полюють яструб великий і малий. Також реєструвався підорлик малий 21 травня 2020 р. та 4 липня 2020 p. Зазначені водойми використовують як кормові майданчики голінасті, зокрема чепура велика та чапля сіра. У липнівересні спостерігаються змішані зграї чисельністю 30-150 особин. Протягом квітня на водоймах реєструвався мігруючий лелека чорний, який тримався у зграях чаплі сірої та чепури великої. Під час міграційного сезону у період спуску води на ставках траплялися чирянка мала, чирянка велика, баранець звичайний (Gallinago gallinago) (3-9 особин), набережник (1-6 особин). Також водойми невеликих розмірів використовують під час міграцій пірникоза чорношия, протягом літа на них реєструвалися зграї великих бакланів (2-10 особин).

Вирощувальні ставки (Боровецькі) мають значні площі і розташовані на окраїні міста, частина водойм межує з відкритими територіями, зокрема полями. Вздовж берегів у значній кількості представлена прибережно-водна рослинність, зокрема очерет і рогіз широколистий. На одній із водойм була наявна колонія мартина звичайного (25-30 пар). Протягом гніздового сезону реєструвались чапля руда, чирянка велика, чернь чубата. Це могло свідчити про гніздування цих видів. Під час весняних міграцій (протягом березняквітня) було зареєстровано зграї попелюха (350-400 особин) (рис. 3б), пірникози чорношийної (до 70 особин), пірникози великої (до 88 особин), широконіски (до 9 особин), чирянки малої (3 особини), черні чубатої (до 15 особин), чирянки великої (до 20 особин), мартина чорнокрилого (Larus fuscus) (до 7 особин). Мартин жовтоногий і звичайний також утворювали значні скупчення. У травні реєстрували скупчення крячка чорного і світлокрилого у спільних міжвидових зграях. На одному зі ставків було виявлено гніздову пару луня очеретяного. Серед інших гніздових видів були наявні пірникоза чорношия (18 пар), пірникоза велика (29 пар), пірникоза мала (1 пара), попелюх (23 пари), лебідь-шипун (1 пара - 5 juv), бугайчик, чапля сіра, вівсянка очеретяна. Також під час літньої линьки спостерігали скупчення лисок (кількість становила 600-700 особин).

Також слід сказати про реєстрацію протягом гніздового сезону чорного шуліки, який полював на прибережних птахів. 9 серпня 2020 р. було зареєстровано 1 особину пірникози сірощокої (Podiceps grisegena). Слід сказати про реєстрацію цього виду у минулі роки, що наголошує на використанні цим видом як міграційних шляхів цих ставків. Весною 
тут було зареєстровано молоду особину орлана-білохвоста, мігруючих i кочуючих канюків звичайних. У весняний період тут реєструвалися зграї лебедя-шипуна кількістю до 40 особин. Вздовж водойм трапляються літуючі особини квака (2-5 особин), які тримались тут протягом сезону.

У вересні постійно реєструється скопа (рис. 4а). На спущених восени ставках (жовтень) було зареєстровано низку куликів, зокрема грицик великий (Limosa limosa), побережник малий, побережник чорногрудий, коловодник лісовий, коловодник великий, брижач, баранець звичайний. Серед інших видів реєструвалися змішані зграї качок, зокрема крех великий, гоголь, шилохвіст, широконіска, свищ, чирянка велика, чирянка мала, чернь чубата, попелюх.

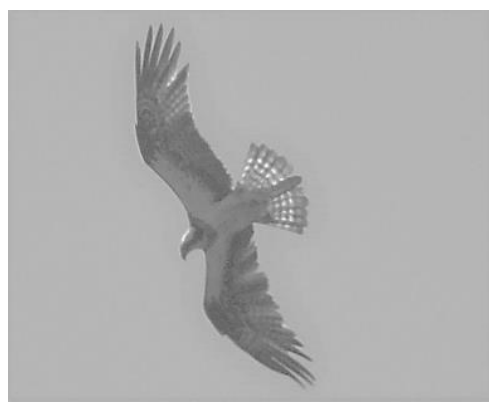

a)

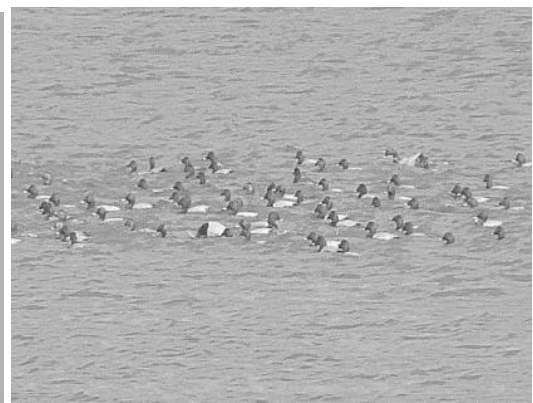

б)

Рис. 4. а) скопа; б) попелюх на рибогосподарських ставах м. Біла Церква

На водоймах протягом сезону, зокрема у листопаді-грудні, реєструються такі види, як канюк звичайний, зимняк, яструб великий, яструб малий та сапсан (Falco peregrinus). Це останній вид, що занесений до ЧКУ.

Отже, дослідне господарство «Нивка» та РГ у Білій Церкві мають багатий видовий склад птахів, проте різняться між собою за кількістю видів на літуванні, гніздуванні та під час міграції. Так, установлено, що на Білоцерківських вирощувальних ставах чисельність та видовий склад водоплавних птахів більший, ніж на господарстві «Нивка». Зазначену територію для гніздування використало 37 видів птахів, а ще 4 види перебувають у статусі ймовірно гніздових. Це підкреслює важливість географічного розташування та ступінь антропогенного навантаження на них.

Ще одним підтвердження цього є приклад іншого господарства. «Іркліївський розсплідник рослиноїдних риб»- це повносистемне РГ 
(утримують плідників і вирощують риб від ікринок до товарної риби), що будувалося задля зариблення Кременчуцького водосховища дворічками рослиноїдних риб для боротьби 3 водоростями і поповненням рибних запасів. Сьогодні воно займається розведенням і реалізацією товарної риби та зарибку. На господарстві присутні такі види, як короп, веслоніс та товстолоб ${ }^{7}$. Риборозплідник розташований у населеному пункті Іркліїв (Черкаська область, Чорнобаївський район), має площу 1237,5507 га та розміщений на Кременчуцькому водосховищі.

Завдяки своїм особливостям риборозплідник суттєво відрізняється від господарства «Нивка» та Білоцерківських рибогосподарських ставків. Через це в осінній період на Іркліївських ставах відбувається скупчення орланів-білохвостів в орієнтовній кількості 50-60 особин (станом на жовтень 2020 р.) (рис. 5). Також на цьому господарстві регулярно реєструється мартин каспійський (Larus ichthyaetus) (ЧКУ).

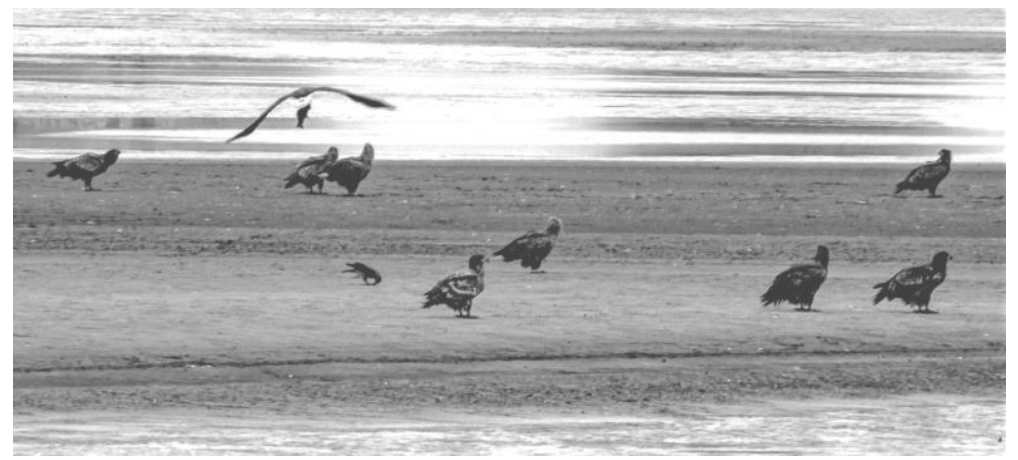

Рис. 5. Скупчення орланів-білохвостів (Haliaeetus albicilla) на рибному господарстві Іркліїв

Також слід сказати про інші риборозплідні господарства, які завдяки своєму географічному розташуванню виконують важливу роль у збереженні біорізноманіття. Так, господарство «Яготинський рибгосп», яке розташоване на р. Супій, має площу 733,6615 га, складається 3 трьох вирощувальних ставів та приваблює чимало рідкісних видів, зокрема тут неодноразово реєстрували такі види, як жовта чапля (Ardeola rulloides), кулик-довгоніг (Himantomus himantomus), нерозень (Anas strepera), чернь білоока, гагара

7 Офіційний сайт Іркліївського риборозплідника.

URL: https://fishbiz.com.ua/cd2019/501_24295_u_f.html. 
червоновола (Gavia stellata), мартин малий (Larus minuta) ${ }^{8}$. Саме через наявність значного біологічного різноманіття територію цього рибного господарства було включено до територій Смарагдової мережі.

РГ ставки, що розташовані вздовж річкових заплав, - це важливі локації, де зберігаються заплавні і водно-болотні території, які важливі для багатьох птахів. Одним із риборозплідників такого типу $\epsilon$ господарство, яке розташоване на р. Стугна в околицях с. Здорівка (Васильківський район Київської області). Тут трапляються такі види, як чорний шуліка, чорний лелека, коловодник ставковий (ЧКУ) (спостереження О.В. Фоміна).

РГ на р. Стугна в околицях с. Таценки, яке розміщено біля території Смарагдової мережі та поблизу території, яка відведена для збереження та використання заказників для природоохоронного призначення (ландшафтного заказника загальнодержавного значення «Козинський»), містить, окрім водоплавних видів, рідкісних хижих птахів, таких як змієїд, підорлик малий, шуліка чорний, орланбілохвіст. На водоймах реєстрували такі види, як кулик-сорока, крячок рябодзьобий (Thalasseus sandvicensis), чернь морська та огар (Tadorna ferruginea) (спостереження C.М. Любченко, О.І. Лавренчук).

\section{2. Порівняльна характеристика видів птахів на міських водоймах та рибних господарств}

Озера системи «Опечень». Розташовані в одному 3 високоурбанізованих районів м. Києва, а саме Оболоні. Каскад озер (був. р. Почайна, через що озера зберегли витягнуту форму) має загальну площу 15,5 га. 3 глибиною $12-15$ м. Озера сильно різняться між собою за ступенем антропогенного навантаження. Найбільш забрудненим озером $\epsilon$ оз. Лугове, яке розташоване поміж промислових забудов, гаражних кооперативів, СТО та залізничної колії. Схема озер системи «Опечень» проілюстрована на рис. 6. Довкола озера зосереджені угруповання прибережної водяної рослинності 3 переважанням очерету. Також зберігся заплавний ліс вздовж лівого берега водойми, де переважають тополя біла та верби.

${ }^{8}$ Мороз В.О., Казанник В.В., Домашевський С.В., Bijlmakers P., Сімон А.О. Нові дані по рідкісних та маловивчених видах птахів Київської області. Беркут. 2015. Т. 24. Вип. 2. С. 87-92. 


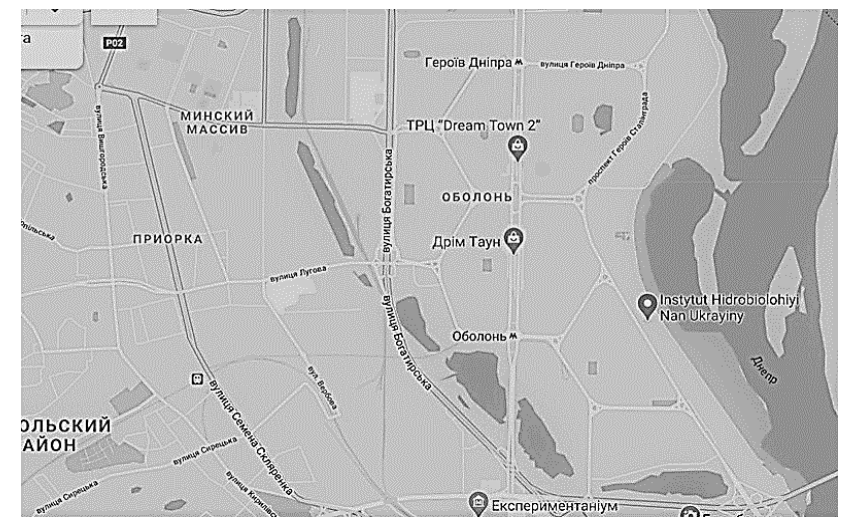

Рис. 6. Система озер «Опечень»

У воді наявні перевищення нафтопродуктів та важких металів. В озері зареєстровано 10 видів риб, таких як карась китайський, краснопірка звичайна, плітка звичайна, лящ, верховодка, вівсянка, бичок-пісочник, гірчак європейський, окунь звичайний, в'юн (Misgurnus fossilis) ${ }^{9}$ та ротан головешка (власні дані). Серед інших водяних тварин реєструвались бобер річковий, ондатра, вуж звичайний та жаба озерна. На цьому озері зустрічаються мартин звичайний, баклан великий, курочка водяна, зозуля звичайна, очеретянка ставкова, очеретянка велика, вівсянка очеретяна. Також неодноразово під час міграцій реєструвалася синиця вусата, зокрема на оз. Кирилівське. Слід зазначити, що територію оз. Йорданське, Кирилівське та Мінське як кормові майданчики активно використовують яструб малий та боривітер звичайний (останній гніздовий вид на високоповерхівках). Також протягом 2015-2018 pр. на оз. Кирилівське та Йорданське реєструвались пірникоза велика. Спостерігалися спроби гніздування. Водойми підлягають інтенсивним процесом евтрофікації, що погіршує умови щодо існування пірникоз. Наприклад, на оз. Набреж, що також підлягає істотному впливу рекреації, було зареєстровано 3-5 пар пірникози великої (2018-2019рр.). Цьому сприяла істотна різниця у якості водного середовища, зокрема рівні евтрофікації, який був значно нижчим. Незважаючи на те, що оз. Лугове зазнає істотного антропогенного забруднення, на ньому присутні угруповання водоплавних птахів, таких як крижень, лиска, водяна курочка та баклан великий (1-3 особини). Також на цьому озері літують мартин жовтоногий, мартин звичайний, рідше

9 Худіяш Ю.М., Причепа М.В, Потрохов О.С., Зіньковський О.Г., Горбатюк Л.О., Коваленко Ю.О., Медовник Д.В. Вплив екологічних умов окремих озер м. Києва на стан іхтіофауни. Рибогосподарська наука Украӥни. Т. 1. (51). С. 44-52. 
трапляються бугайчик та крячок річковий. Оз. Мінське (останнє в каскаді) характеризується наявністю значного видового багатства вищих водяних рослин, які відсутні у водоймах, розташованих нижче. Серед виявлених у озері риб слід зазначити наявність таких видів, як карась китайський, плітка, окунь, щука, краснопірка, верховодка, бичок-пісочник, лящ, плоскирка (Blicca bjoerkna).

На озерах системи «Опечень», які зазнають меншого антропогенного впливу, зокрема оз. Кирилівське, зафіксоване більше розмаїття іхтіофауни, де нараховувалось 27 видів риб ${ }^{10}$ Серед представників іхтіофауни слід виокремити наявність таких видів, як головень (Squalius cephalus), в'язь (Leuciscus idus), щука, судак (Sander lucioperca), окунь, верховодка, краснопірка, карась китайський, бичок тупоносий західний (Proterorhinus semilunaris), йорж звичайний. Під час міграції на цих озерах були зареєстровані такі види, як чирянка велика, широконіска, попелюх, мородунка (Xenus cinereus), набережник, баклан великий. Загалом кількість птахів несуттєва. Домінуючими гніздовими видами є крижень і лиска. Слід зауважити, що чисельність птахів, як правило, незначна. 3 хижих видів на озерах реєстрували такі види, як яструб малий (рис. 7) та великий, підсоколик великий, канюк звичайний та боривітер звичайний. На прикладі озер системи «Опечень» добре видно вплив урбанізації на населення птахів. Негативну роль відіграє знищення прилеглих до озер берегових заростей. Це перш за все стосується таких видів, як синьошийка, лиска, водяна курочка, бугайчик, очеретянки. Порівняно із 2017 та 2018 pp. у 2019 р. після значної реконструкції озер «Опечень», зокрема оз. Йорданського, відбулися суттєві зміни кількості водно-болотних птахів. Так, лисок залишилося лише 3 пари, хоча у 2015-2018 pр. тут гніздилося 12-16 пар. Іншим вагомим чинником, що впливає на успішність гніздування водно-болотних видів риб, є наявність великого угруповання сірих пацюків (Rattus norvegicus), що мешкає на прилеглій до водойм території міста.

Завдяки розташованим довкола озер заплавних гаїв, у яких наявні угрупування тополі білої (Populus alba) та верб (Salix sp.), гніздяться дендрофільні представники орнітофауни. Також на заплавних частинах на оз. Кирилівське, зокрема на заболочених ділянках гаю вздовж оз. Кирилівське, реєструвались канюк звичайний та яструб малий. Також у 2020 р. восени в межах оз. Йорданське реєструвався зимняк (Buteo lagopus).

${ }^{10}$ Худіяш Ю.М., Причепа М.В, Потрохов О.С., Зіньковський О.Г., Горбатюк Л.О., Коваленко Ю.О., Медовник Д.В. Вплив екологічних умов окремих озер м. Києва на стан іхтіофауни. Рибогосподарська наука Украӥни. Т. 1. (51). С. 44-52. 


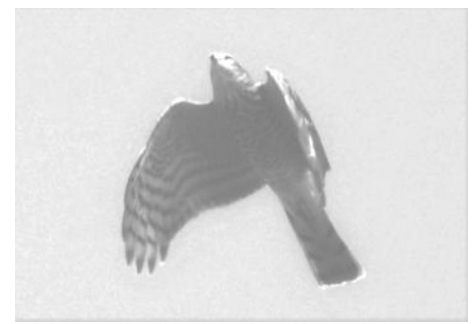

a)

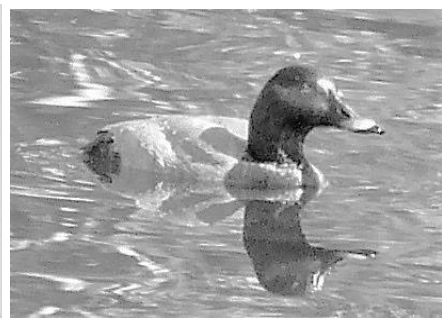

б)

Рис. 7. а) яструб малий (Accipiter nisus) на оз. Кирилівське;

б) попелюх (Aythya ferina) на оз. Йорданське системи «Опечень»

Горіхуватські ставки. Розташовані на території Національного парку «Голосіївський» на р. Горіхуватка - права притока р. Либідь, довжина яких становить близько 4 км., протікають лісовою місцевістю. Ставки мають видовжену форму глибиною 1,5-2 м, зазнають значного рекреаційного навантаження. Перший ставок замулений та зарослий вищою водяною рослинністю. Верхній ставок порівняно невеликий і також сильно замулений, нижній має найбільшу площу, відносно не зарослий, біля нього розташований сосновий гай. Саме цей став має найбільше рекреаційне навантаження ${ }^{11}$. Схема ставів наведена на рис. 8.

Особливістю цих водойм $є$ розташування каскаду в межах лісу. Це створює специфічні умови для існування флори й фауни. На якісний склад середовища впливає рекреація, викликана розвитком інфраструктури довкола цієї системи водойм. На формування біорізноманіття водойм впливають численні фактори. До них належать особливості вузьких долин, де знаходяться водотоки, на яких створено ставки, стрімкі заліснені схили, що іноді впритул підходять до водного об'єкта. У зв'язку з практичною відсутністю заплав на водотоках, розміщених у цьому урочищі, можливості для заболочення прилеглих до них частин місцевості обмежені.

${ }^{11}$ Вишневецький В.І. Малі річки Києва. Київ : Інтерпрес ЛТД, 2013. 84 с. 


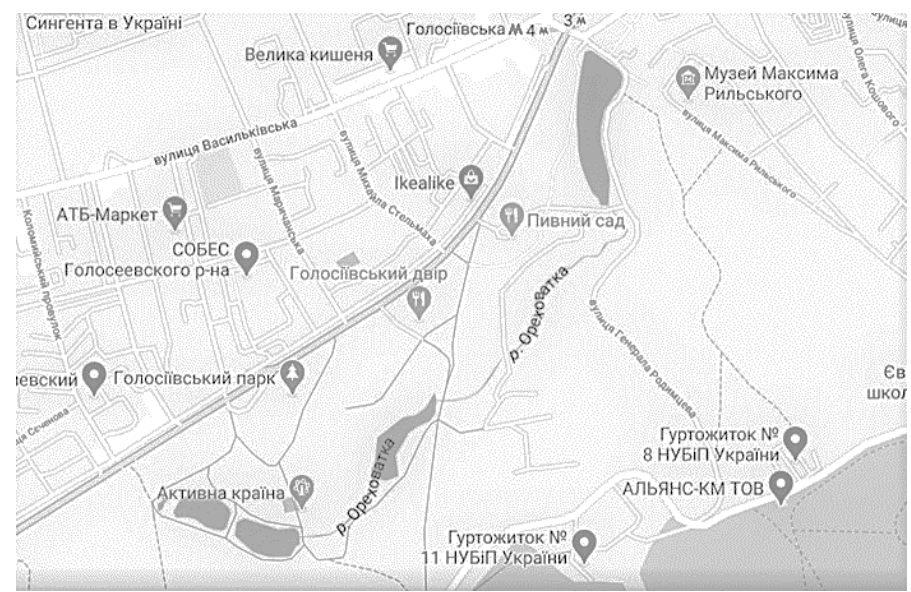

Рис. 8. Каскад ставів р. Горіхуватка

Вони трапляються лише подекуди. До них належать, зокрема, ділянки чорновільхових лісових боліт ${ }^{12}$. Прибережні зони утворені локальними угрупованнями очерету, рогози, осоки, мілководдя заростями глечиків жовтих (Nymphar lutea) та ряски малої (Lemna minor). Тут наявні такі види риб, як карась китайський, окунь річковий, бичок-гонець, бичок-пісочник, колючка триголкова, вівсянка, амурський чебачок, гірчак звичайний. Варто зазначити, що за період із 1983 р. по 2001-2002 рр. зі складу іхтіофауни зникло 5 видів риб (плітка звичайна, пічкур звичайний, карась звичайний, білий товстолоб та білий амур). Зазначені зміни у видовому складі можуть бути пов'язані з радикальним очищенням водойми. Водночас у видовому складі з'явилися гірчак звичайний, чебачок амурський, карась сріблястий (Carassius superspecies auratus) та окунь звичайний. Не виключено, що ці зміни також могли позначитись на видовому складі птахів, які існували на цій території ${ }^{1314}$. Слід сказати про наявність у водоймах і вздовж Оріхуватського струмка окремих представників земноводних, таких як жаба гостроморда, жаба трав'яна, райка, жаба

\footnotetext{
${ }^{12}$ Романенко О.В., Арсан О.М., Кіпніс Л.С., Ситник Ю.М. Екологічні проблеми київських водойм і прилеглих територій. Київ : Наукова думка, 2015. 190 с.

${ }_{13}$ Кундиев В.А., Сытник Ю.М., Шевченко И.Г., Чеченюк И.И. Ихтиофауна Голосеевских прудов (г. Киев). Гидробиологический журнал. 2006. Т. 42. № 6. С. 41-46.

${ }^{14}$ Кундієв В.А., Ситник Ю.М. Іхтіофауна водойм міської зони Києва. Сучасні проблеми теоретичної та практичної іхтіології : тези I Міжнародної іхтіологічної науково-практичної конференції (Київ і Канів, 18-21 вересня 2008 р.). Канів, 2008. C. $98-100$.
} 
озерна, ропуха сіра, кумка звичайна, а також тритон гребінчастий (Triturus cristatus). Ссавці представлені двома гідрофільними видами, такими як ондатра та рясоніжка велика (Neomys fodiens). Під час міграції та/або протягом зимового періоду на цих ставках зупиняються такі птахи, як зимняк, чирянка мала, попелюх, пірникоза мала, свищ (рис. 9), осоїд, а також канюк звичайний в інші періоди. На ставах наявні гніздові угруповання крижня, лиски, курочки водяної, очеретянки великої, бугайчика, синьошийки, рибалочки звичайної (Alcedo atthis). На заболочених ділянках водойм траплялися пастушок, плиска біла, синиця вусата, чапля сіра. У зимовий період на Горіхуватському ставку (№ 1) реєструвалися зграї крижня чисельністю до 150-200 особин. Серед гніздових можна виокремити також 25 дендрофільних видів птахів. приурочених до лісових біотопів. Також слід зауважити про використання зазначеної території окремими представниками орнітофауни, такими як підсоколик великий, боривітер звичайний, яструб малий і яструб великий, мартин звичайний, крячок річковий, як кормових майданчиків.

Отже, стави та озера, що розміщені в межах м. Києва, сильно поступаються рибним господарствам як за видовим складом, так і за чисельністю птахів, які використовують природні ділянки в урбанізованому середовищі для гніздування чи харчування.

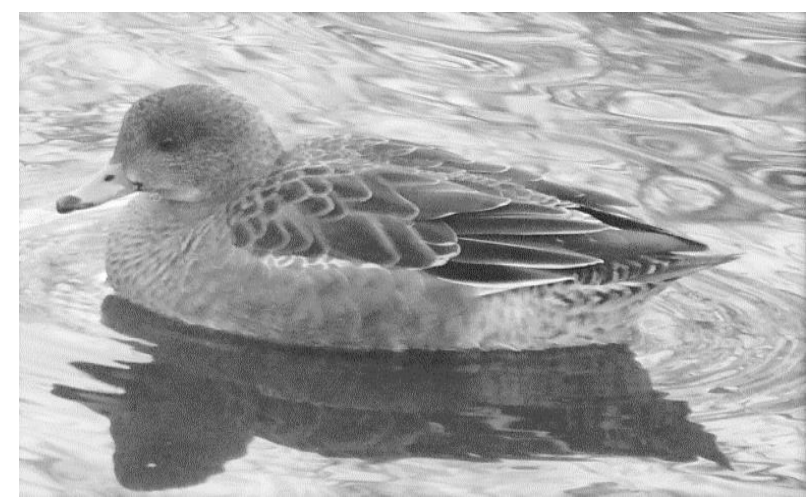

Рис. 9. Свищ на одному з Горіхуватських ставків

Водойми, які зазнають антропогенного забруднення та рекреаційного навантаження, рідше використовуються як кормові та гніздові ділянки, зокрема, хижими та водно-болотними видами. Загалом на досліджуваних територіях було зареєстровано 99 видів птахів (табл. 1), 19 із них занесені до Червоної книги України (2009р.). 
Найбільша кількість птахів була виявлена на території рибного господарства «Нивки», а саме 96 видів, дещо менше видів виявлено на рибних господарства Білої Церкви (83). На схожих за принципом та будовою на РГ ставках, які розміщені на території м. Києва, але на яких не проводиться рибогосподарська діяльність (озера системи «Опечень» та Горіхуватські ставки (Голосіївського парку)), незважаючи на різний ступінь антропогенного навантаження, зафіксовано значно менше видове різноманіття (28 та 34 видів птахів відповідно). Результати досліджень наведені у табл. 1.

Таблиця 1

Видовий склад птахів і статус видів у районі досліджень

\begin{tabular}{|c|c|c|c|c|c|}
\hline № & Назва виду & $\begin{array}{c}\text { Статус } \\
\text { видів у РГ } \\
\text { «Нивка» }\end{array}$ & $\begin{array}{c}\text { Статус } \\
\text { видів у } \\
\text { ставках } \\
\text { РГ БЦ } \\
\end{array}$ & $\begin{array}{c}\text { Статус видів } \\
\text { у оз. } \\
\text { «Опечень» }\end{array}$ & $\begin{array}{c}\text { Статус видів у } \\
\text { Горіхуватських } \\
\text { ставках }\end{array}$ \\
\hline 1 & 2 & 3 & 4 & 5 & 6 \\
\hline 1 & Gavia arctica & M & - & - & - \\
\hline 2 & $\begin{array}{c}\text { Podiceps } \\
\text { cristatus }\end{array}$ & $\Gamma$ & $\Gamma$ & $\Gamma(?)$ & - \\
\hline 3 & $\begin{array}{l}\text { Podiceps } \\
\text { grisegena }\end{array}$ & - & M & - & - \\
\hline 4 & $\begin{array}{l}\text { Podiceps } \\
\text { nigricollis }\end{array}$ & $\Gamma(?)$ & $\Gamma$ & - & - \\
\hline 5 & $\begin{array}{l}\text { Podiceps } \\
\text { ruficollis }\end{array}$ & $\Gamma(?)$ & $\Gamma$ & - & M \\
\hline 6 & $\begin{array}{c}\text { Phalacrocorax } \\
\text { carbo }\end{array}$ & Л & Л & Л & - \\
\hline 7 & Ardea alba & $\Gamma(?)$ & $\Gamma(?)$ & - & - \\
\hline 8 & Ardea cinerea & $\Gamma$ & $\Gamma$ & - & Л \\
\hline 9 & $\begin{array}{c}\text { Ardea } \\
\text { purpurea }\end{array}$ & M & $\Gamma(?)$ & - & - \\
\hline 10 & $\begin{array}{l}\text { Ixobrychys } \\
\text { minutes }\end{array}$ & $\Gamma$ & $\Gamma$ & $\Gamma$ & Л \\
\hline 11 & $\begin{array}{l}\text { Botaurus } \\
\text { stellaris }\end{array}$ & $\Gamma(?)$ & $\Gamma$ & - & - \\
\hline 12 & $\begin{array}{l}\text { Nycticorax } \\
\text { nycticorax }\end{array}$ & M & $\Gamma(?)$ & - & Л \\
\hline 13 & $\begin{array}{l}\text { Ciconia } \\
\text { ciconia }\end{array}$ & Л & $\Gamma$ & - & - \\
\hline 14 & Ciconia nigra* & Л & $\mathrm{M}$ & - & - \\
\hline 15 & Anser anser & M & M & - & - \\
\hline 16 & Anser albifrons & M & M & - & - \\
\hline 17 & Anser fabalis & M & - & - & - \\
\hline
\end{tabular}


Продовження таблці 1

\begin{tabular}{|c|c|c|c|c|c|}
\hline 1 & 2 & 3 & 4 & 5 & 6 \\
\hline 18 & Cygnus olor & $\Gamma$ & $\bar{\Gamma}$ & - & - \\
\hline 19 & Anas crecca & $\mathrm{M}$ & $\mathrm{M}$ & - & $\mathrm{M}$ \\
\hline 20 & $\begin{array}{c}\text { Anas } \\
\text { querquedula }\end{array}$ & $\Gamma(?)$ & $\Gamma(?)$ & - & - \\
\hline 21 & Anas penelope & $\mathrm{M}$ & $\mathrm{M}$ & - & $\mathrm{M}$ \\
\hline 22 & Anas clypeata & $\mathrm{M}$ & $\mathrm{M}$ & - & $\mathrm{M}$ \\
\hline 23 & $\begin{array}{c}\text { Anas } \\
\text { phatyrhynchos }\end{array}$ & $\Gamma$ & $\Gamma$ & $\Gamma$ & $\Gamma$ \\
\hline 24 & Anas acuta & - & $\mathrm{M}$ & - & - \\
\hline 25 & $\begin{array}{c}\text { Anser } \\
\text { strepera* }\end{array}$ & M & & & \\
\hline 26 & Aythya fuligula & $\Gamma(?)$ & Л & M & - \\
\hline 27 & Aythya marila & M & - & - & - \\
\hline 28 & Aythya ferina & $\mathrm{M}$ & $\Gamma$ & $\mathrm{M}$ & $\mathrm{M}$ \\
\hline 29 & $\begin{array}{l}\text { Bucephala } \\
\text { clangula* }\end{array}$ & M & M & - & - \\
\hline 30 & $\begin{array}{c}\text { Mergus } \\
\text { merganser }\end{array}$ & M & M & - & - \\
\hline 31 & $\begin{array}{c}\text { Aix } \\
\text { galericulata }\end{array}$ & M & - & - & - \\
\hline 32 & $\begin{array}{c}\text { Pandion } \\
\text { haliaetus* }\end{array}$ & M & M & - & - \\
\hline 33 & $\begin{array}{c}\text { Pernis } \\
\text { apivorus }\end{array}$ & $\Gamma(?)$ & M & M & M \\
\hline 34 & $\begin{array}{c}\text { Milvus } \\
\text { migrans* }\end{array}$ & $\Gamma$ & Л & - & - \\
\hline 35 & $\begin{array}{c}\text { Circus } \\
\text { cyaneus* }\end{array}$ & - & M & - & - \\
\hline 36 & $\begin{array}{c}\text { Circus } \\
\text { pugargus } *\end{array}$ & M & M & - & - \\
\hline 37 & $\begin{array}{c}\text { Circus } \\
\text { aeroginosus }\end{array}$ & $\Gamma$ & $\Gamma$ & - & M \\
\hline 38 & Accipiter nisus & $\Gamma$ & Л & Л & $\Gamma(?)$ \\
\hline 39 & $\begin{array}{c}\text { Accipiter } \\
\text { gentilis }\end{array}$ & $\Gamma$ & Л & M & $\Gamma(?)$ \\
\hline 40 & Buteo lagopus & - & $\mathrm{M}$ & $\mathrm{M}$ & $\mathrm{M}$ \\
\hline 41 & Buteo buteo & $\Gamma$ & $\mathrm{M}$ & Л & Л \\
\hline 42 & $\begin{array}{l}\text { Circaetus } \\
\text { gallicus* }\end{array}$ & Л & - & - & - \\
\hline 40 & Aquila clanga* & $\mathrm{M}$ & - & - & - \\
\hline 41 & $\begin{array}{c}\text { Aquila } \\
\text { pomarina* }\end{array}$ & Л & M & M & - \\
\hline 42 & $\begin{array}{l}\text { Haliaeetus } \\
\text { albicilla* }\end{array}$ & Л & M & - & M \\
\hline 43 & $\begin{array}{c}\text { Falco } \\
\text { peregrines } *\end{array}$ & M & M & M & - \\
\hline
\end{tabular}


Продовження таблці 1

\begin{tabular}{|c|c|c|c|c|c|}
\hline 1 & 2 & 3 & 4 & 5 & 6 \\
\hline 44 & $\begin{array}{c}\text { Falco } \\
\text { vespertinus }\end{array}$ & $\mathrm{M}$ & - & - & - \\
\hline 45 & Falco subbuteo & Л & Л & Л & $\Gamma(?)$ \\
\hline 46 & $\begin{array}{c}\text { Falco } \\
\text { columbarius }\end{array}$ & M & & & \\
\hline 47 & $\begin{array}{c}\text { Falco } \\
\text { tinnunculus }\end{array}$ & $\Gamma(?)$ & Л & Л & Л \\
\hline 49 & Grus grus* & - & $\mathrm{M}$ & - & - \\
\hline 50 & $\begin{array}{c}\text { Rallus } \\
\text { aquaticus }\end{array}$ & $\Gamma$ & $\Gamma$ & - & $\Gamma(?)$ \\
\hline 51 & Crex crex & $\Gamma(?)$ & $\Gamma(?)$ & & - \\
\hline 52 & Porzana parva & $\Gamma(?)$ & $\Gamma$ & - & - \\
\hline 53 & $\begin{array}{l}\text { Porzana } \\
\text { porzana }\end{array}$ & $\Gamma(?)$ & $\Gamma(?)$ & $\Gamma(?)$ & - \\
\hline 54 & Fulica atra & $\Gamma$ & $\Gamma$ & $\Gamma$ & $\Gamma$ \\
\hline 55 & $\begin{array}{l}\text { Gallinula } \\
\text { chloropus }\end{array}$ & $\Gamma$ & $\Gamma$ & $\Gamma$ & $\Gamma$ \\
\hline 56 & $\begin{array}{c}\text { Charadrius } \\
\text { dubius }\end{array}$ & M & $\Gamma$ & - & - \\
\hline 57 & $\begin{array}{l}\text { Vanellus } \\
\text { vanellus }\end{array}$ & $\Gamma(?)$ & $\Gamma$ & - & - \\
\hline 58 & $\begin{array}{c}\text { Tringa } \\
\text { ochropus }\end{array}$ & M & M & M & - \\
\hline 59 & $\begin{array}{c}\text { Tringa } \\
\text { glareola }\end{array}$ & M & M & - & - \\
\hline 60 & Tringa totanus & $\mathrm{M}$ & $\Gamma$ & - & - \\
\hline 61 & $\begin{array}{c}\text { Tringa } \\
\text { nebularia }\end{array}$ & M & M & M & - \\
\hline 62 & $\begin{array}{c}\text { Tringa } \\
\text { stagnatilis } *\end{array}$ & M & M & - & - \\
\hline 63 & Xеnus cinereus & - & $?$ & M & - \\
\hline 64 & $\begin{array}{c}\text { Actitis } \\
\text { hypoleucos }\end{array}$ & M & $\Gamma(?)$ & M & - \\
\hline 65 & $\begin{array}{c}\text { Philomachus } \\
\text { pugnax }\end{array}$ & - & M & - & - \\
\hline 66 & Calidris minuta & $\mathrm{M}$ & $\mathrm{M}$ & - & - \\
\hline 67 & $\begin{array}{c}\text { Calidris } \\
\text { ferruginea }\end{array}$ & $\mathrm{M}$ & M & - & - \\
\hline 68 & Calidris alpina & M & M & - & - \\
\hline 69 & $\begin{array}{c}\text { Calidris } \\
\text { temminckii }\end{array}$ & M & M & - & - \\
\hline 70 & $\begin{array}{l}\text { Gallinago } \\
\text { gallinago }\end{array}$ & M & M & - & - \\
\hline 71 & $\begin{array}{l}\text { Gallinago } \\
\text { media* }\end{array}$ & - & M & - & - \\
\hline 72 & Limosa limosa & $\mathrm{M}$ & $\mathrm{M}$ & - & - \\
\hline 73 & $\begin{array}{c}\text { Larus } \\
\text { ridibundus }\end{array}$ & $\Gamma$ & $\Gamma$ & Л & Л \\
\hline 74 & Larus minutus $*$ & $\mathrm{M}$ & - & - & - \\
\hline
\end{tabular}


Закінчення таблці 1

\begin{tabular}{|c|c|c|c|c|c|}
\hline 1 & 2 & 3 & 4 & 5 & 6 \\
\hline 75 & $\begin{array}{c}\text { Larus } \\
\text { cachinnans }\end{array}$ & Л & Л & Л & Л \\
\hline 76 & Larus fuscus & $\mathrm{M}$ & $\mathrm{M}$ & - & - \\
\hline 77 & Larus canus & $\mathrm{M}$ & $\mathrm{M}$ & $\mathrm{M}$ & - \\
\hline 78 & $\begin{array}{l}\text { Chlidonias } \\
\text { hybrida }\end{array}$ & M & $\Gamma$ & - & - \\
\hline 79 & $\begin{array}{l}\text { Chlidonias } \\
\text { niger }\end{array}$ & $\Gamma$ & M & - & - \\
\hline 80 & $\begin{array}{l}\text { Chlidonias } \\
\text { leucopterus }\end{array}$ & M & M & - & - \\
\hline 81 & Sterna hirundo & $\Gamma(?)$ & $\Gamma$ & Л & $\pi$ \\
\hline 82 & $\begin{array}{c}\text { Sterna } \\
\text { albifrons } *\end{array}$ & - & M & - & - \\
\hline 83 & $\begin{array}{l}\text { Cuculus } \\
\text { canorus } \\
\end{array}$ & $\Gamma$ & $\Gamma$ & $\Gamma$ & $\Gamma$ \\
\hline 84 & Strix flammeus & $\mathrm{M}$ & - & - & - \\
\hline 85 & Alcedo atthis & $\Gamma$ & $\Gamma$ & $\Gamma$ & $\Gamma$ \\
\hline 86 & Riparia riparia & $\Gamma$ & $\Gamma$ & Л & Л \\
\hline 87 & $\begin{array}{c}\text { Motacilla } \\
\text { cinerea }\end{array}$ & $\Gamma$ & $\Gamma$ & - & - \\
\hline 88 & $\begin{array}{c}\text { Motacilla } \\
\text { citreola }\end{array}$ & M & - & - & - \\
\hline 89 & Motacilla alba & $\Gamma$ & $\Gamma$ & $\Gamma$ & $\Gamma$ \\
\hline 90 & $\begin{array}{l}\text { Locustella } \\
\text { luscinioides }\end{array}$ & $\Gamma$ & $\Gamma$ & - & - \\
\hline 91 & $\begin{array}{l}\text { Locustella } \\
\text { fluviatilis }\end{array}$ & $\Gamma$ & - & - & - \\
\hline 92 & $\begin{array}{l}\text { Acrocephalus } \\
\text { schoenobaenus }\end{array}$ & $\Gamma$ & $\Gamma$ & - & - \\
\hline 93 & $\begin{array}{c}\text { Acrocephalus } \\
\text { scirpaceus }\end{array}$ & $\Gamma$ & $\Gamma$ & $\Gamma$ & $\Gamma$ \\
\hline 94 & $\begin{array}{c}\text { Acrocephalus } \\
\text { palustris }\end{array}$ & $\Gamma$ & $\Gamma$ & - & - \\
\hline 95 & $\begin{array}{l}\text { Acrocephalus } \\
\text { arundinaceus }\end{array}$ & $\Gamma$ & $\Gamma$ & $\Gamma$ & $\Gamma$ \\
\hline 96 & $\begin{array}{c}\text { Luscinia } \\
\text { svecica }\end{array}$ & $\Gamma$ & $\Gamma$ & - & $\Gamma$ \\
\hline 97 & $\begin{array}{c}\text { Panurus } \\
\text { biarmicus }\end{array}$ & $\Gamma$ & $\Gamma$ & M & $\mathrm{M}$ \\
\hline 98 & $\begin{array}{c}\text { Remiz } \\
\text { pendulinus }\end{array}$ & $\Gamma$ & $\Gamma$ & $\Gamma$ & $\Gamma$ \\
\hline 99 & $\begin{array}{c}\text { Emberiza } \\
\text { schoeniclus }\end{array}$ & $\Gamma$ & $\Gamma$ & M & M \\
\hline & Всього & 96 & 83 & 34 & 28 \\
\hline
\end{tabular}

Примітка: Г-гніздовий, Г (?) - ймовірно гніздовий, Л -літуючий, М-мігруючий, * види, щьо занесені до Червоної книги Украӥни

Як видно 3 табл. 1, птахи під час гніздового та міграційного сезонів РГ використовують у два рази частіше, ніж водойми, що розташовані в 
межах міста. Це відбувається завдяки багатству біотопів, що утворились на рибних господарствах, а також завдяки їх межуванню із заплавними лісами й полями. Ці території відіграють важливу роль у збагаченні та примноженні видового різноманіття птахів та інших тварин в умовах катастрофічного браку типово диких територій, які знищуються внаслідок шкідливої господарської діяльності людини.

Варто зауважити, що птахи на рибогосподарських водоймах виконують санітарну та удобрювальну функції. Так, рибоїдні види перш за все використовують у їжу хворих риб. Завдяки цьому на господарстві відбувається попередження епідемій, пов'язаних із розвитком інфекційних, грибкових чи інших хвороб. Наприклад, кулики як марозообентософаги споживають молюсків та інших безхребетних, які є носіями небезпечних захворювань коропових риб.

Також птахи часто споживають види риб, які не належать до об'єктів аквакультури (карась китайський, амурський чебачок, верховодка, вівсянка, бички тощо). Таким чином, птахи зменшують кількість харчових конкурентів об'єктам аквакультури, через що відбувається заощадження часто високовартісних кормів для годівлі цінних видів риб.

Качки, харчуючись на господарстві, позбавляють ставок від значного заростання водоростями, які у надмірній кількості, особливо у літній період, можуть порушувати газовий режим у водоймі, викликаючи задуху в риб.

Відходи життєдіяльності качки можуть слугувати субстратом для розвитку мікроорганізмів, завдяки яким через трофічний ланцюг підвищується природна кормова база ставка. Через це господарство може додатково отримувати більший приріст товарної риби.

Неабияку роль птахи відіграють як санітари, підбираючи, зокрема, снулу та хвору рибу, забезпечуючи нормальний санітарний стан на водоймах. Важливу роль у цьому відіграють сірі ворони, крук, шуліка чорний, орлан-білохвіст. Незважаючи на те, що низка птахів споживають рибу як види-іхтіофауги, окремі з них є рідкісними (лелека чорний, скопа, гоголь, пірникоза сірощока, крячок малий). 3 огляду на їх незначну кількість шкода від них несуттєва.

У штучно-створених водоймах (паркові ставки та каскадні озера) за тривалий час існування без належного догляду з боку людини починають відбуватися деструктивні процеси, зокрема заболочення, заростання водойм вищою водною рослинністю. Це погіршує екологічні умови шляхом порушення нормального розвитку фото- та зоопланктону, бентосу, що приводить до змін у іхтіофауні. Через це штучно створені водойми потребують контролю та нерідко поліпшення екологічного стану. Такі заходи можуть наблизити ці водойми за рівнем біорізноманіття до 
ставових господарств, отже, підвищити рекреаційну цінність паркових територій. Яскравим прикладом таких водойм $є$ Совські ставки, де збереглись осередки біологічного розмаїття водоплавних видів птахів, які відтворюються у межах міста. Яскраво ілюструє ситуацію зі збереженням цієї території наявність колонії мартина звичайного і крячка чорного, гніздового угруповання чаплі сірої, бугайчика, синиці вусатої, попелюха та черні чубатої (останні два види у Києві на гніздуванні зустрічаються дуже рідко). Проте, як і щодо окультурення озер із каскаду «Опечень», Совські стави планують забудувати високоповерхівками і знищити водно-болотні угіддя назавжди.

Незважаючи на це, присутність птахів на рибних господарствах вважається небажаною, через що працівники вживають заходів щодо їх відлякування чи навіть відстрілу в сезон міграції чи гніздування. Через такі дії можуть страждати рідкісні види птахів, що охороняються низкою міжнародних конвенцій та Червоною книгою України.

\section{ВИСНОВКИ}

Рибні господарства $є$ цінним надбанням для збереження рідкісних видів птахів, які штучно змогли повноцінно замінити втрачені природні осередки середовища існування для багатьох видів. При цьому важливим $\epsilon$ те, що за рибогосподарськими ставками проводиться догляд, завдяки чому ставки не заростають і не замулюються, тобто підтримується певний баланс. При цьому паркові водойми, за яким не проводиться РГ-догляд, але здійснюється антропогенне забруднення та рекреаційне навантаження, мають суттєво менший видовий склад птахів. Яскраво ілюструють це водойми Оріхуватських ставків, де було зареєстровано 28 видів проти 96 і 83 видів на Нивках та Білоцерківських ставках відповідно. Через це виникає необхідність поліпшення загального екологічного стану малих річок та озер, що розташовані у межах міста. Особливо це стосується каскаду озер «Опечень», де через надмірний антропогенний пресинг відбулося збіднення якісного та кількісного складу орнітофауни.

Завдяки достатній кормовій базі РГ ставків становлять велику привабливість для гніздування різних видів, які розширюють межі ареалів або здійснюють точкові гніздування.

Перебування птахів на РГ становить для них певну загрозу через упереджену думку про їх шкідливість для економічного та санітарного благополуччя господарства. Через це існує необхідність поглибленого дослідження специфіки перебування птахів на рибних господарствах задля отримання нових наукових результатів. Вони в подальшому могли б стати основою для пошуків шляхів виокремлення рибних господарств в окрему категорію природно-заповідного фонду України 
як осередків біологічного різноманіття, зокрема рідкісних видів тварин. На цьому наголошують дані стосовно наявності видів, які підлягають охороні національного та міжнародного законодавства. Крім того, РГ ставків відіграють важливу роль як місця линьки, годівлі під час транскордонних міграцій для багатьох видів птахів.

\section{АНОТАЦІЯ}

Розглянуто видовий склад птахів рибогосподарських ставів (дослідне господарство «Нивка» та Білоцерківські РГ ставів) та озер міської зони Києва («Опечень», Горіхуватські стави).

Встановлено, що за кількістю видів переважали Нивка та РГ ставів Білої Церкви, де нараховувалось 96 та 83 види, проти 43 і 28 в межах «Опечені» та Горіхуватських ставів відповідно. Показано, що рибогосподарські стави завдяки біотопічному розмаїттю незалежно від географічного розташування (Полісся чи Лісостеп) відіграють важливу роль у гніздуванні, годівлі та міграції багатьох представників орнітофауни, зокрема водоплавних та довколаводних видів. Проте існує низка проблем, пов'язаних із посиленням рекреаційного навантаження та браконьєрством на цих водоймах.

3 огляду на той факт, що на території досліджуваних господарств реєструються види, які включені до Бернської, Бонської конвенцій, МСОП та Червоної книги України, вони мають природоохоронне значення й викликають високий рівень зацікавленості не лише для науковців і бервотчерів, але й для пересічних громадян і політиків, оскільки рідкісні види $є$ не лише національним надбанням України, але й міжнародним для всієї Європи.

\section{ЛIТЕРАТУРА}

1. Андрющенко А.І., Алимов С.І. Ставове рибництво. Київ : Видавничий центр НАУ, 2008. 636 с.

2. Вишневський В.І. Малі річки Києва. Київ : Інтерпрес ЛТД, 2013. $84 \mathrm{c}$.

3. Казанник В.В., Турчик А.В., Яненко В.О. Водно-болотяна орнітофауна Святошинських ставків м. Києва та ії̈ сезонні зміни. Вісник Дніпропетровського агро-економічного університету. 2014. № 1 (33). C. $170-174$.

4. Костюшин В.А., Домашевский С.В., Грищенко В.Г. Материалы по распространению черного коршуна (Milvus migrans) в Киевской области в гнездовый период. Беркут. 2015. Т. 24. Вып 1. С. 42-46.

5. Кундиев В.А., Сытник Ю.М., Шевченко И.Г., Чеченюк И.И. Ихтиофауна Голосеевских прудов (г. Киев). Гидробиологический журнал. 2006. Т. 42. № 6. С. 41-46. 
6. Кундієв В.А., Ситник Ю.М. Іхтіофауна водойм міської зони Києва. Сучасні проблеми теоретичної та практичної іхтіологї : тези I Міжнародної іхтіологічної науково-практичної конференції. (Київ і Канів, 18-21 вересня 2008 р.). Канів, 2008. С. 98-100.

7. Худіяш Ю.М., Причепа М.В, Потрохов О.С., Зіньковський О.Г., Горбатюк Л.О., Коваленко Ю.О., Медовник Д.В. Вплив екологічних умов окремих озер м. Києва на стан іхтіофауни. Рибогосподарська наука України. Т. 1 (51). С. 44-52. DOI: https://doi.org/10.15407/fsu2020.01.028.

8. Мороз В.О., Казанник В.В., Домашевський С.B., Bijlmakers P., Сімон А.О. Нові дані по рідкісних та маловивчених видах птахів Київської області. Беркут. 2015. Т. 24. Вип. 2. С. 87-92.

9. Причепа М.В. Видовий склад і населення хижих та гідрофільних птахів лук та водно-болотних угідь окремих частин Києва та його околиць. Беркут. 2019. Т. 28. Вип. 1-2. С. 6-14.

10. Романенко О.В., Арсан О.М., Кіпніс Л.С., Ситник Ю.М. Екологічні проблеми київських водойм і прилеглих територій. Київ : Наукова думка, 2015. 190 с.

11. Офіційний сайт ДП «Дослідне господарство «Нивка»». URL: http://www.if.org.ua/index.php/uk/departments/nyvka (дата звернення: 01.12.2020).

12. Офіційний сайт Іркліївського риборозплідника. URL: https://fishbiz.com.ua/cd2019/501_24295_u_f.html (дата звернення: 01.12.2020).

\section{Information about the authors:} Prychepa M. V.,

Candidate of Biological Sciences, Researcher at the Department of Biological of Biology of Fish Reproduction Institute of Hydrobiology of National Academy of Science of Ukraine 12, Heroyiv Stalingrada avenue, Kyiv, 04210, Ukraine

Kovalenko Yu. O.,

Senior Engineer at the Department of Biological of Biology of Fish Reproduction Institute of Hydrobiology of National Academy of Science of Ukraine 12, Heroyiv Stalingrada avenue, Kyiv, 04210, Ukraine 